\title{
Development of Mouse Two-Cell Embryos to Hatched Blastocysts in a Medium Supplemented with Bovine Amniotic Fluid
}

\author{
Akira OKANO and Masashi TAKAHASHI \\ Department of Animal Reproduction, National Institute of \\ Animal Industry, Tsukuba Norin Kenkyu Danchi, \\ Ibaraki-ken, 305
}

(Received April 13, 1994)

\begin{abstract}
This study was conducted to determine the effect of bovine, porcine and avian amniotic fluid (AmF) on the in vitro development of mouse embryos. The growth rates from 2cell embryo through to hatched blastocyst (HBlast) were examined in whole $\mathrm{AmF}$ or in culture media supplemented with and without $\mathrm{AmF}$ for $96 \mathrm{~h}$. Whole bovine, porcine and avian $\mathrm{AmF}$ were not effective for the development of mouse embryos cultured in vitro. In a BSA-free M16 medium supplemented with $10 \%$ bovine $\mathrm{AmF}$, the development of 2 -cell embryos was equal to that in M 16 supplemented with BSA. The effective factor in bovine AmF was destroyed by heat treatment at $100^{\circ} \mathrm{C}$ for $5 \mathrm{~min}$, and was not absorbed with Dextran-charcoal treatment. The moleculsr weight (MW) of this fraction was less than $10^{4}$. Therefore, this factor is not a steroid or a lipid but presumably a polypeptide of $\mathrm{MW}$ less than $10^{4}$.
\end{abstract}

Anim. Sci. Technol. (Jpn.) 65 (10) : 923-927, 1994

Key words : bovine, amniotic fluid, mouse embryo, hatching

Various culture media have been developed for culturing early mammalian embryo in vitro. However, most culture media are either supplemented with 10 to $20 \%$ bovine serum, bovine serum albumin (BSA) or serum of the same species, and the effective factors in the sera of the some species or in BSA are still unknown ${ }^{4,7}$. On the other hand, Gianaroli $e t$ $a .^{2)}$ found that human amniotic fuid (AmF) was effective for in vitro fertilization of human oocytes and their subsequent culture as well as in vitro culture of mouse embryo. DORFMANN et al. ${ }^{1}$ reported that human $\mathrm{AmF}$ was a more effective medium for the in vitro culture of mouse embryos than defined synthetic media. The effective factor in avian and porcine AmF on early embryos cultured in vitro is also un- known. The effects of bovine AmF and allantoic fluid as culture media for mouse embryos have been studied ${ }^{3)}$. Others ${ }^{1-3)}$ have proposed that the effect of AmF on culturing embryos depends on the fact that $\mathrm{AmF}$ originates from the developing fetus.

Our study was conducted to determine the effects of bovine, porcine and avian AmF on the development of mouse early embryos cultured in vitro from 2-cell embryos through to hatched blastocyts (HBlast).

\section{Materials and Methods}

Collection and preparation of amniotic fluid: Bovine and porcine $\mathrm{AmF}$ were directly obtained by syringe from the amniotic cavity of removed and incised uteri. Bovine $\mathrm{AmF}$ was 
collected at the slaughterhouse from five fetal calves of approximately 70 days gestation. Fetal ages were estimated from their crownrump length ${ }^{6}$. Porcine $A m F$ was collected from an experimental slaughterhouse in our Institute from five pigs of 20 to 30 days gestation. Avian AmF was directly taken from the amniotic cavity of fifty fertilized eggs at 6 days following brooding, by manually cracking the egg shell and exposing the air sac. To remove the cells and other debris, AmF from the three species was centrifuged and then inactivated by heating at $56^{\circ} \mathrm{C}$ for $30 \mathrm{~min}$, and stored at $-80^{\circ} \mathrm{C}$ until used in experiments. AmF from the three species was pooled and filtered through a $0.45 \mu \mathrm{m}$ pore size filter unit (Toyo Roshi, Tokyo, Japan) to remove microorganisms.

Treatment and fractionation of bovine amniotic fluid: Bovine AmF was treated as follows: 1) heated at $100^{\circ} \mathrm{C}$ for $5 \mathrm{mim}$ (H. treat) or, 2) steroids and lipids were absorbed as follows : a $10 \%$ volume of Dextran-charcoal suspension (DC) was added to $\mathrm{AmF}$ in a tube, and the mixture was shaken for $15 \mathrm{~min}$ at room temperature. The tube was centrifuged at $1500 \mathrm{G}$ for $15 \mathrm{~min}$, and supernatant was removed as DC treated $A m F, \quad D C$ was prepared by dissolving $25 \mathrm{mg}$ Dextran T70 (Pharmacia, Uppsala, Sweden) in $100 \mathrm{~m} l$ PBS and adding $250 \mathrm{mg}$ Norit A charcoal (J.T. BAKER, Phillipsberg, NJ). Bovine AmF was was fractionated based on molecular weight (MW) as follows : 3 ) MW less than $\left.10^{4}, 4\right) \mathrm{MW}$ between $10^{4}$ to $\left.3 \times 10^{4}, 5\right) \mathrm{MW}$ more than $3 \times 10^{4}$. MW fractions of AmF were separated by centrifugation at $1500 \mathrm{~g}$, over 20 min, using Ultracento-10 and -30 (Tosoh, Tokyo, Japan). Ultracento-10 and -30 cuts off over $99 \%$ of molecules whose MW are larger than $10^{4}$ and $3 \times 10^{1}$, respectively.

Collection of 2-cell mouse embryos: Adult female ICR mice were kept on a schedule of 12 $\mathrm{h}$ light and $12 \mathrm{~h}$ darkness. They were injected with 5 IU PMSG, and $24 \mathrm{~h}$ later, ovulation was induced by 5 IU HCG. They were mated with
ICR male mice and checked the following morning for the presence of copulatory plug. Two-cell embryos were flushed from the oviducts with PBI approximately 44 to $46 \mathrm{~h}$ after mating ${ }^{8)}$.

Culture and observation of mouse embryos: Two-cell embryos were placed in $50 \mu t$ drop of culture medium, and covered with mineral oil (Squibb, Princeton, NJ). The embryos were incubated at $37^{\circ} \mathrm{C}$ in $5 \% \mathrm{CO}_{2} / 95 \%$ air, and were observed after $96 \mathrm{~h}$ for HBlast formation. The control medium was M 16 supplemented with BSA $(4 \mathrm{mg} / \mathrm{m} l)^{8)}$. Growth rates of embryo culture in whole AmF from the three species were compared to those in M16. In addition, the growth rates of embryos cultured in M16 and/ or BSA-free M 16 (M16NBSA) supplemented with $10 \%(\mathrm{~V} / \mathrm{V})$ avian, porcine and bovine $\mathrm{AmF}$, or the fractions of bovine AmF, were also compared with each other.

Statistical analysis: Differences in the development of 2-cell embryos through to HBlast were analyzed by $\chi^{2}$ test.

\section{Results}

The results of development of 2-cell embryos through to HBlast, cultured in whole bovine porcine and avian AmF, are shown in Fig. 1. Twenty-nine of forty-eight 2-cell embryos $(60.4 \%)$ cultured in M 16 (control) reached HBlast level. One of forty-nine 2-cell embryos $(2.0 \%)$ cultured in bovine $\mathrm{AmF}$, none of forty-six 2-cell embryos $(0 \%)$ cultured in porcine AmF, and four of forty-six 2-cell embryos (8.7\%) cultured in avian AmF, developed into HBlasts, respectively, Almost half of the 2-cell embryos culture in M16NBSA could not develop beyond 2-cell stage. A few of the 2-cell embryos cultured in M16NBSA developed into morulae and approximately $10 \%$ of embryos developed into HBlasts.

The results of the development of 2-cell embryos into HBlasts cultured in M-16 and supplemented with $10 \%$ bovine, porcine and avian AmF are shown in Fig. 2. Thirty-eight 
of fifty-four 2-cell embryos $(70.4 \%)$ cultured in M 16 (control) developed into HBlast. Sixteen of twenty-seven 2-cell embryos (59.3\%) cultured in M 16 supplemented with bovine $\mathrm{AmF}$, twelve of twenty-eight 2-cell embryos (42.9\%) cultured in M16 supplemented with porcine $\mathrm{AmF}$, and thirty-three of fifty 2-cell embryos (66.6\%) cultured in M16 supplemented with avian $\mathrm{AmF}$, developed into BHlasts, respective-

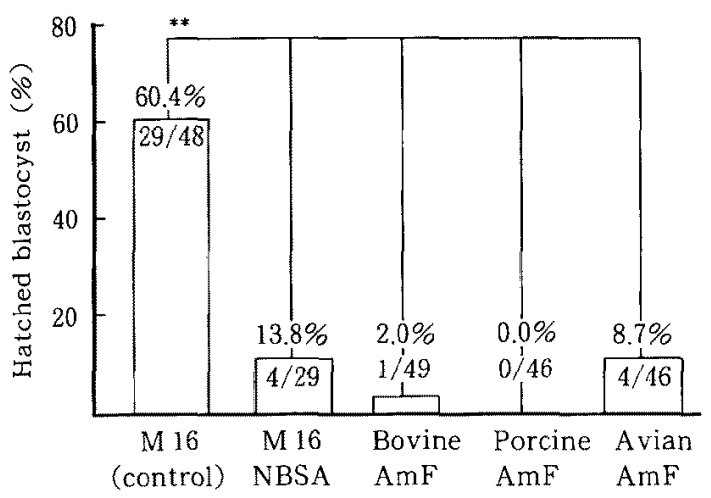

Fig. 1. Development of mouse 2-cell embryos to hatched blastocysts in M16 or in whole bovine, porcine and avian amniotic fluid.

M 16 : containing $4 \mathrm{mg} / \mathrm{ml}$ BSA., M16NBSA : not containing BSA., AmF : amniotic fluid., ${ }^{* *}: \mathrm{P}<$ 0.01



Fig. 2. Development of mouse 2-cell embryos to hatched blastocysts in M16 containing $10 \%$ bovine, porcine and avian amniotic fluid.

M-16: containing $4 \mathrm{mg} / \mathrm{ml}$ BSA., AmF : amniotic fluid., N.S. : not significant 1y. No significant difference in the growth rates from 2-cell embryos to HBlasts for M 16 (control) and M 16 supplemented with AmF from the three species could be detected. When M16NBSA was supplemented with $10 \%$ AmF from the three species, the growth rates of 2-cell embryos to HBlasts were thirty-seven of fift $y$-three 2-cell embryos $(69.8 \%)$ (M 16, control), six of forty-four 2-cell embryos (13.6\%) in M16NBSA without BSA, thirty-six of fortyfive 2-cell embryos (80.0\%) in M16NBSA supplemented with bovine $A m F$, thirteen of forty-three 2 -cell embryos (30.2\%) supplemented with porcine $\mathrm{AmF}$, and twenty-one of forty 2-cell embryos (52.5\%) in M16NBSA supplemented with avian $\mathrm{AmF}$, respectively (Fig. 3). The growth rates of 2 -cell embryos cultured in either M16 (control) or in M16NBSA supplemented with bovine $A m F$ were significantly higher than those for embryos in M16NBSA supplemented with porcine and avian $\mathrm{AmF}$.

The growth rates of 2-cell embryos cultured in M16NBSA supplemented with treated bovine $\mathrm{AmF}$ are shown in Fig. 4. Twentynine of fifty-five 2-cell embryos (52.7\%) cultured in M 16 (control) developed into HBlasts.

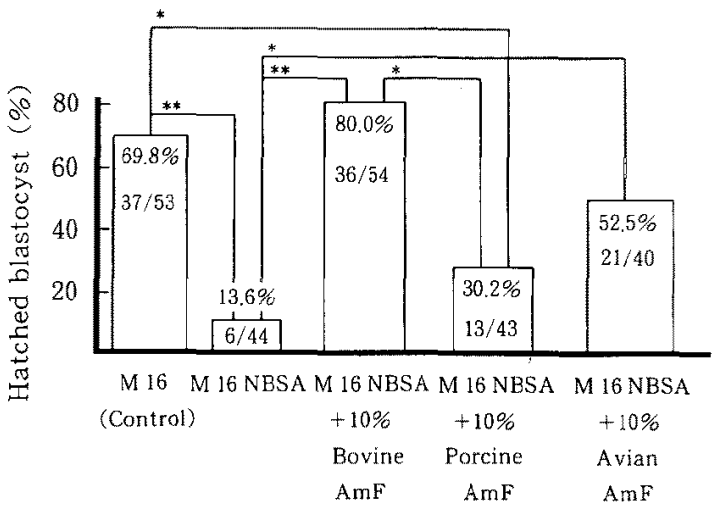

Fig. 3. Development of mouse 2-cell embryos to hatched blastocysts in M16NBSA containing $10 \%$ bovine, porcine and avian amniotic fluid. M 16 : containing $4 \mathrm{~m} \mathrm{~g} / \mathrm{m} l$ BSA., M 16 NBSA : nol containing BSA., AmF : amniotic fluid., * $\mathrm{P}<$ $0.05 .{ }^{* *}: \mathrm{P}<0.01$ 




Fig. 4. Development of mouse 2-cell embryos to hatched blastocysts in M16 NBSA added 10\% bovine and treated amniotic fluid.

M 16 : containing $4 \mathrm{mg} / \mathrm{ml}$ BSA., M $16 \mathrm{NBSA}$ : not containing BSA., AmF : amniotic fluid., I : M 16 NBSA $+10 \%$ bovine AmF., II : M16 NBSA $+10 \%$ heat treated bovine AmF., III : M 16NBSA + 10\% Dextran-charcoal treated bovine AmF., IV : M 16 NBSA $+10 \% \mathrm{MW}<10^{4}$ fraction of bovine $\mathrm{AmF}$., $\mathrm{V}: \mathrm{M} 16 \mathrm{NBSA}+10 \% \quad \mathrm{MW} \quad 1-3 \times 10^{4}$ fraction of bovine AmF., VI: M $16 \mathrm{NBSA}+10 \%$ MW $3 \times 10^{4}$ fraction of bovine $A m F .{ }^{*}: \mathrm{P}<0.05 .,{ }^{* *}: \mathrm{P}<0.01$

Eleven of fifty-five 2-cell embryos $(20.0 \%)$ cultured in M16NBSA and thirty-seven of seventy 2-cell embryos (52.9\%) cultured in M16NBSA supplemented with non treated AmF developed into HBlasts, respectively. Five of forty-seven 2 -cell embryos $(10.6 \%)$ cultured in M16NBSA supplemented with $\mathrm{H}$ treated AmF and twenty-six of forty-seven 2-cell embryos (56.5\%) cultured in M16NBSA supplemented with DC treated AmF developed into HBlasts, respectively. The growth rates of 2-cell embryos to HBlasts were thirty-nine of sixtytwo 2-cell $(62.9 \%)$ cultured in M16NBSA supplemented with a low MW fraction (less than $10^{4}$ ) of $\mathrm{AmF}$, and eighteen of fifty-seven 2 - cell embryos (31.6\%) in M 16 NBSA supplemented with both a middle MW fraction $\left(10^{4}\right.$ to $3 \times 10^{4}$ ) and a high MW fraction (more than $3 \times$ $\left.10^{4}\right)$, respectively. Growth rates in M16NBSA supplemented with $10 \% \mathrm{AmF}, \mathrm{DC}$ treated AmF or a low MW fraction of AmF were higher than those in M16NBSA supplemented with other treated AmF.

\section{Discussion}

Gianarolli et al. ${ }^{2)}$ and DoRfmann et al. ${ }^{1)}$ reported that human $\mathrm{AmF}$ is an effective culture medium for mouse embryos in vitro. Although JAved et al. ${ }^{3)}$ demonstrated that 2-cell mouse embryos could be cultured through to blastocysts in $100 \%$ fresh bovine $\mathrm{AmF}$, bovine AmF which had been frozen had an adverse effect on development. In our study, Ml6NBSA supplemented with $10 \%$ bovine AmF which was frozen and pooled, was not detrimental to the development of 2-cell mouse embryos through to HBlasts.

The results of the present study indicate that intact bovine, porcine and avian AmF were detrimental to the development of mouse embryos cultured in vitro. Although AmF from the three species had a detrimental effect on mouse embryo development, the addition of $10 \% \mathrm{AmF}$ to M16NBSA gave similar results to that of M16 containing $4 \mathrm{mg} / \mathrm{ml}$ BSA. The concentration of the detrimental factor in AmF was diluted ten times by M16NBSA, so the negative effect was eliminated by a dilution of $\mathrm{AmF}$ and an eventually positive effect remained. AmF generally contains a low level of total protein. Since the protein level in bovine AmF at around 70 days of pregnancy is approximately $150 \mu \mathrm{g} / \mathrm{ml}$, this being approximated by $1 / 27$ of $4 \mathrm{mg} / \mathrm{m} l \mathrm{BSA}$ in $\mathrm{M}-16^{8)}$, eventually a final protein level of M16NBSA supplemented with $10 \%$ bovine AmF equals approximately $1 / 270$ of M 16 with BSA ( $4 \mathrm{mg}$ ) $\mathrm{m} l$ ). Two major proteins in bovine $\mathrm{AmF}$ at around 70 days of pregnancy are $\alpha$-fetoprotein (AFP) and BSA, and AFP is dominant over $\mathrm{BSA}^{5)}$. Ultracento-10 and -30 can cut off over $99 \%$ of molecules whose $\mathrm{MW}$ are larger than $10^{4}$ and $3 \times 10^{4}$, respectively. If the cut-off fractions with Ultracento contain trace amounts of AFP and/or BSA, their effect could be negligible on the development of 2-cell mouse embryos through to blastocysts.

Our findings demonstrate that bovine $\mathrm{AmF}$ 
contains an effective factor for mouse embryo development. If bovine $\mathrm{AmF}$ contains an effective factor for the development of 2-cell mouse embryos through to HBlasts, it would likely be destroyed by heat treatment at $100^{\circ} \mathrm{C}$ for $5 \mathrm{~min}$, and not be absorbed with DC. This factor is not likely to be a steroid or a lipid because it was not absorbable with DC. Presumably it would be a polypeptide having low MW (less than $10^{4}$ ) in consideration of its instability toward heat.

\section{References}

1) Dorfmann, A.D., M. Bustillo, S.D. Bender, G. ReEd, P. Robinson, J.D. Schulman and E.F. FUGGER, Cell-free human amniotic fluid as culture medium for mouse and human embryos. Fert. Steril, 51 : 671-674. 1989.

2) Gianaroni, L., R. Seracchioli, A.P. Ferraretti, A. Trounson C. Flamigni and L. Bovicelli, The successful use of human amniotic fluid for mouse embryo culture and human in vitro fertilization, embryo culture, and transfer. Fert. Steril, $46:$ 907-913, 1986.

3) JAVED, M.H. and W. WRIGHTR, Jr, Bovine amniotic and allantoic fluids for the culture of murine embryos. Theriogenology $34: 445-460$. 1990.

4) KANE, M.T., Culture media and culture of early embryos. Theriogenology, $27 ; 49-75,1987$.

5) OKano, A., Y. Shloya, T. Obata and R. Fukuhara, Specific protein in bovine allantoic fluid and amniotic fluid. Jpn. J. Zootech. Sci., 49 : 276-282. 1978.

6) OKano, A., Y. IZAiKe, K. Shimada, T. OISHI and T. MiYASHICE, Fetal development in the Japanese Black Cattle. Jpn. J. Anim. Repord., 31 : 147149. 1985. (in Japanese).

7) Quinn, P.C., C. Barros and D.G. WhitTigham, Preservation of hamster oocytes to assay the fertilizing capacity of human spermatozoa. $\mathrm{J}$. Reprod. Fert., 66 : 161-168. 1982.

8) Whittigham, D.G., Culture of mouse ova. J. Repord. Fert. (suppl), 14: 7-21. 1971.

\title{
マウス肧の体外培養液へのウシ羊膜液添加の効果
}

\author{
岡野 彰・高橋昌志
}

農林水産省畜産試験場，茨城県筑波農林研究団地 305

マウス胚の体外培養のための培養液へ，ウシブタおよびニワトリ羊膜漼添加の効果を明らかにしよ うとした．羊膜液および羊膜液を添加した培養液中で，マウス 2 細胞期肧を培養し，96 時間後における 透明常脱出肧盤胞への発育率を檢討した，3動物種からの羊膜液之も無处理のままでは，マウス胚の体 外培養液として用いた場合は全く効果がなく，むしろ肧の発育を阻害する傾向を示した，しかしウシ血 清アルブミンを含まない M 16 培養液にウシ羊膜液を $10 \%$ 添加して，マゥヌ 2 細胞期还を体外培養する と，ウシ血清アルブミンを含むM 16 培盖液之同程度に，透明帯脱出肧盤胞へ発育させえた．マウス 2 細 胞期肧を透明帯脱出肧盤胞へ発育させるのに有効なっシ羊膜中の因子は, $100^{\circ} \mathrm{C} て ゙ 5$ 分間の加熱处理で 失活し，゙゙キストランーチャコールで吸収さ枕なっった。このことより，この因子は脂質やステロイド様 の物質ではなく，分子量 $10^{4}$ 以下のペプチドあるいは遊離アミノ酸と推定された．

日畜会報，65 (10)：923-927，1994 